\title{
Assessing development and the idea of development in the 1950s in Brazil
}

\author{
RAFAEL ROSSOTTO IORIS \\ ANTONIO AUGUSTO ROSSOTTO IORIS*
}

The decade of 1950s was a crucial period of the industrialization of the Brazilian economy. The dominant school of thought was the national-developmentalism, which was not restricted to the sphere of economic production but also encompassed political and socio-cultural processes of change. Combining repression, persuasion and paternalism, the national state took a significantly political and economic responsibility in the social, material and symbolic modernization during the Vargas and Kubitschek administrations. However, internal disputes, foreign demands and a long legacy of socio-spatial inequalities prevented the achievement of more socially inclusive goals, leading a legacy of unanswered questions that still have currency today.

Keywords: Brazil, national-developmentalism, Vargas, Kubitschek, technocratic planning.

JEL Classification: O14; O25; O54; L52.

\section{INTRODUCTION}

At the dawn of the 1950s Brazil had a population of around fifty five million and an economy largely defined by the production and export of agricultural commodities. The decade witnessed nonetheless a profound transformation as distinct sectors of the Brazilian society engaged in implementing a substantial redefinition of the nation's traditional agrarian basis. Along these lines, fast-paced growth by means of deepening the process of import substitution industrialization would

\footnotetext{
* Respectively, Assistant Professor of Latin American History, University of Denver, USA. E-mail: rafael. ioris@du.edu Lecturer in Geography, University of Aberdeen, UK. E-mail: a.ioris@ed.ac.uk Submitted: 27/October/2011; Approved: 7/August, 2012.
} 
become a political priority for the most influential sectors of government officials and public intellectuals in the period. While in agreement insofar as the general goal of fast paced economic growth, these different social segments would put forward different views on what national development should mean and a rich debate pertaining to the strategies of achieving such an objective would unfold. In the end, however, a national strategy centred on absolute rates of economic growth prevailed, at the exclusion of more socially inclusive policies.

The prevailing literature on the developmental decade of the 1950s in Brazil has posited that despite rising political disputes, the goal of fast-paced growth had produced a purported nation-wide 'developmental consensus.' Some of the most influential works advancing this position include Benevides (1976); Carone (985); Draibe (1985); Guimarães (2005); Ianni (1963, 1986); Lafer (2002); Martins (1968); Napoleão (1988); Oliveira (1991); Rodrigues (1994); Silva and Carneiro (1983); Skidmore (1967); and Weffort (1978). To be sure, the claim that 1950s in Brazil were marked by an upbeat patriotic sentiment disseminated among several upper and middle-income sectors seems indeed warranted and these historical dynamics were reflected in many events that helped shape the prevailing self-image of the nation constructed at the time. In 1958, for instance, Brazil would win the Soccer World Cup for the first time and the Bossa Nova music was introduced to world audiences. In tandem, governmental administrations were quick to cunningly exploit the symbolism of the social and economic transformations taking place in the urban and rural landscape. Domestically produced automobiles began taking the streets and the growing numbers of highways interconnecting the country's immense territory, and, as the decade came to an end, Brasília, Brazil's new futuristic-looking administrative capital was inaugurated in the heartland of the country thus purportedly marking the nation's dawn of a new era.

These transformative events notwithstanding, the long legacy of underdevelopment remained a vivid reality in the country as the majority of its citizens continued to be illiterate and to face dire living conditions on a daily basis. The industrial growth, urban regeneration and artistic creativity of the period would be all but restricted to a minority of the population, especially those living in the wealthier parts of the large cities in the Southeast Region. Furthermore, the alleged unity around national development that purportedly characterized the period would not be capable of disguising the intense process of class differentiation and uneven development that eventually culminated in the institutional rupture of the early 1960s which heralded twenty-one long years of military dictatorship.

Combining a micro-level historical analysis with a critical theoretical frame of reference, the present article seeks to argue that despite the different view on nation development, state-led reforms taking place in the 1950s would ultimately lead to the implementation of very selective, resilient, and ultimately regressive economic policies with long-lasting consequences for the country. Specifically in the second half of the decade promoted a close linkage established between national and foreign capital under the aegis of the national developmental state, at the expense of a - much expected among trade unions and critical intellectuals - more socially 
inclusive path of national development. As will be shown below, despite the clear existence of alternative positions that could lead to a more autonomous and farreaching agenda, the federal Brazilian administration would pursue a conservative, and ultimately exclusionary, course of industrial promotion and economic growth. These partial transformations took place under a vibrant, but superficial, discourse of modernization and national harmony, which paradoxically fostered social and institutional contradictions that would influence the national politics and the economy of Brazil for the next half century.

The article is organized into four distinct sections. The first presents the main lines of the conceptual framework set forth to examine the complex relationships existing between state and social actors within any dynamic of development promotion. The second and third parts are focused on providing the main political and ideological dynamics of the period so that the historical trajectory leading to the consolidation of the very specific developmental notions that underlined the governmental efforts of mid-twentieth century Brazil can be unveiled. In the closing section we advance the lines of a prospective reflection about the ways in which the experiences of the 1950s impacts the country to the present day.

\section{STATE AND SOCIETY RELATIONS WITHIN FAST-PACE INDUSTRIALIZATION: REVISITING THE DEBATES}

The literature on the political economy of Brazilian development in the postwar period is vast and has been constantly expanding. One of the most studied aspects of this phase has been the intensification of import substitution policies aimed at simultaneously stimulating economic growth and protecting national manufactures from external shocks and competition. Despite their important contributions, most of these neglected to combine the political, social, ideological, and even idiosyncratic variables which should also be taken into consideration when evaluating the achievements and failures of such a process of development promotion. In that context, in addition to the works cited above, see Bresser-Pereira (2006); Colistete (2007); Fleury and Fleury (2006); Leff (1968); Lessa (1964); Lobo (2009); Saad-Filho and Johnson (2005); Tyler (1976); and Welch (2006).

Akin to the experiences taking place in some other Latin American countries, in Brazil the post-World War II period corresponded to the transition from an agrarian and export oriented economy into an increasingly urbanized and industrial society. Along these historical lines, the conversion to heavy industrial production was the one of the main priorities of the political and intellectual agendas of the time. The Brazilian government would indeed seize the opportunity and attempted to amend the country's traditional pattern of insertion into the international economy, as a commodity exporter. Moreover, any nationalistic goal pursued in the period would similarly face the structural constraints of the rising Cold War that consolidated the U.S. supremacy in the Western hemisphere, which required 
special negotiation skills and a sense of political opportunism from the Brazilian diplomatic staff (King, 1970; Stallings, 1978; Veganzones, 1997; and Wise, 2003).

The economic and geographical complexity of transitioning to an urban, industrialized society created major challenges for providing and maintaining the necessary leadership to provide minimum levels of social cohesion. As a result, the central government would emerge as the only political player capable of formulating and enacting new strategies of capital accumulation while at the same time, controlling the increasingly conflictive private interests being mobilized under a process of fast industrialization. In historical terms the national state effectively acted as the main agent coordinating the processes of change from a predominant rural society to the aspired industrialized and urbanized country. ${ }^{1}$ Finally, as will be demonstrated below, the transition envisaged and articulated by the national state vividly incorporated a developmental rhetoric - which was closely informed by foreign capital - within idiosyncratic public policies that reproduced, and often magnified, the social inequalities that permeated nation building since its foundation.

As we proceed, it is important to point out that, in our view, far from being a neutral entity that promotes the common good, the structures of the central state combined centralized and diffuse sources of authority in conformity with the fundamental features of political economy, becoming thus profoundly embedded in social relations taking place in a particular spatio-temporal context. The capitalist state indeed constitutes a political arena of disputes operating in a continuous process of formation and superseding of a contingent social equilibrium (Jessop, 2007). In this sense, the state apparatus is both an instrument of the hegemonic social classes but it also maintains a partial autonomy needed to mediate class struggles and pursue other policies beyond the realm of the economy. Furthermore, the selectivity of state interventions is not given in advance but rather is the result of the interplay between state priorities and socio-political contestation within and beyond state institutions. Still, and in spite its core function as guarantor of the needed conditions for social cohesion and capital accumulation, the relationship the state established with the larger society is not purely on a repressive basis (Jessop, 1990, 2008).

Instead, one the most innovative features of the capitalist state is that, at the same time demands consent, the state 'educates' the consented of the importance of consenting amidst an attempt of absorbing the entire civil society (Gramsci, 1971, p. 259). The political and economic strategies of the state becomes, therefore, entangled in inter-sectoral exchanges and spatialized relations that take place under specific historical configurations, as experienced in Brazil in the 1950s. Moreover, the development of capitalist relations of production promotes also a growing internationalisation of state activities beyond the limits of its national territory (Glassman, 1999).

\footnotetext{
${ }^{1}$ On the format of this so-called 'state of compromise' which would perform the role of leading the process of Import Substitute Industrialization in Brazil; see Ianni $(1963,1986)$ and especially Weffort (1978).
} 
Local dynamics remain nonetheless especially relevant to understanding the complexity of the relations between state and society. Particularly in the case of Latin America, the national state is not only described by its capitalist and political features but also by profoundly gendered and patriarchal relations (Cravey, 1998). National governments have indeed played a crucial role in articulating the interests of domestic groups and the demands of foreign capital while promoting fast-pace industrialization in post-World War II Latin America. Along these lines and on the basis of this brief conceptual revision, we seek to reconstruct in the next two sections the ways in which fast-paced state-led development was pursued in midtwentieth century Brazil. This purpose therein is to unveil the processes wherein specific social sectors and political forces were favoured in detriment to larger segments of the national population.

\section{IMPORT-SUBSTITUTIVE INDUSTRIALIZATION AND THE EMERGENCE OF NATIONAL-DEVELOPMENTALISM}

On January 31, 1951, after having conducted what had been until then the most vibrant and geographically extended presidential campaign in the history of the country, Getulio Vargas was, once again, Brazil's President, in a mandate that would last until his suicide in August 1954. The former leader of the 1930 military nationalistic revolt that put in place a corporatist-like state and initiated the process of import-substitution industrialization was back in power poised to implement an ambitious agenda of economic development and social reform. The national context of restored democratic rule ushered in at the onset of the World War required, however, a new set of political skills that the aged politician ultimately would prove lacking (see D’Araújo, 1982; and Fundação Getulio Vargas, 2001). Vargas' political platform was largely inspired in the notion that the goal of industrialization had to be strengthened amidst the opportunities created by the reconfigured international division of labour in the post-war period. This view was closely in tune with the framework of historical analysis formulated by the new generation of economists coalesced at the Economic Commission for Latin America (ECLA), created by the Economic and Social Council of the United Nations in $1948 .^{2}$

Since its inception, ECLA's recommendations were basically informed by the ideas and leadership provided by its first head officer, the Argentine economist Raul Prebisch. Already in 1946, when serving as President of the Argentine Central Bank, Prebisch drew attention to the 'peripheral' nature of the economic insertion of Latin American countries in the world market. His main theoretical contribution was the controversial Doctrine of Unequal Exchange, which described the international economic system as one where the industrial centre dominates the agrarian periph-

\footnotetext{
2 The commission is nowadays described as the Economic Commission for Latin America and the Caribbean (ECLAC), with headquarters in Santiago de Chile.
} 
ery through a deterioration of the exchange terms that persistently prevents the development of the subordinated countries (Love, 1980). Along these lines, Prebisch argued in favour of a concerted process of industrialization to be guided by the national governments of the region. Such an understanding would achieve a paramount importance and serve as a key reference for those arguing in favour of fastpaced industrialization in Latin America. For a revision of the synthetic works on the Commission, see Furtado (1985); Love (1998); and Rodrigues (1981).

Even though the World War II had initially impacted the Brazilian economy in a positive sense (mainly by increasing the country's exports of food supplies), once the period of reconstruction in Europe began, late in the 1940s, foreign sources of capital were primarily targeted to the countries directly involved in the battlefronts and the paradigmatic example was the Marshal Plan. Similarly, the monetary surplus that Brazil had gained during the years of conflict went then into a steep decline, and, as a result a profound redefinition of the national economic priorities would become increasingly present among the country's political and intellectual elites. The experiences of the war had nonetheless helped foster the goal of industrialization among military leaders who, as important power brokers in the authoritarian regime of New State (1937-1945), saw the need to create war-related (chemical and aeronautical) industries as a vital component of a policy of national security (Carone, 1985; Skidmore, 1967). In contrast to the restricted industrial policies of the war period, however, within the context of the post-war circumstances a new paradigm for promoting national development, which would go far beyond the military concerns of the previous Vargas administration, would take shape in Brazil. This new development approach was inspired on the notion that industrialization was a sine qua non condition for securing economic self-sufficiency and that a more direct involvement of the national government in a variety of economic activities, not only the production of basic industrial goods, was needed. With these tenets in mind, the Brazilian government would increasingly adopt a more aggressive role in the promotion of heavy industrialization in the 1950s.

This broad goal was seen as attainable by resorting to governmental policies which sought to control import tariffs on items to be produced domestically, provide credit assistance to nationally owned industries, and artificially regulate the exchange rate (at the cost of rising inflation and deficits) to assure that domestically produced items, even if non-competitive, could be exported. Numerous public utilities and state companies were created to fill gaps in productive sectors and infrastructure areas beyond the reach or the capability of private investors. The domestic market was to be favoured via periodical wage increases and by offering subsidized investments to consumers of public services, such as transportation, energy, and communication networks. At the same time, there was a controlled internationalisation of the economy and, since 1955 it was allowed to import machinery and equipment without exchange cover (in the form of direct foreign investment). The significant intensification of heavy industrial production in the Brazil throughout the 1950s is summarized in Table 1 below. 
Table 1: Growth Rates of the Brazilian Economy (selected years)

\begin{tabular}{cccccc}
\hline Year & $\begin{array}{c}\text { GDP } \\
(\%)\end{array}$ & $\begin{array}{c}\text { GDP per } \\
\text { capita }(\%)\end{array}$ & $\begin{array}{c}\text { Industry } \\
(\%)\end{array}$ & $\begin{array}{c}\text { Agriculture } \\
(\%)\end{array}$ & $\begin{array}{c}\text { Inflation } \\
\text { rate (\%) }\end{array}$ \\
\hline 1950 & 6.5 & 4.0 & 11.3 & 1.5 & 11.2 \\
1953 & 2.5 & $(0.5)$ & 8.7 & 0.2 & 15.3 \\
1955 & 6.9 & 3.7 & 9.9 & 7.7 & 16.3 \\
1958 & 7.7 & 4.6 & 16.2 & 2.0 & 11.1 \\
1960 & 9.7 & 6.6 & 9.6 & 4.9 & 26.3 \\
1964 & 2.9 & 0.0 & 5.2 & 1.3 & 87.3 \\
\hline
\end{tabular}

Compiled from various sources quoted in Tyler (1976)

These figures would support the view that the 1950s in Brazil were indeed developmental years if considered in terms of absolute economic growth. The period nonetheless was not only marked by fast-pace growth but also by a widespread developmental ideology which would be labelled as national-developmentalism and which exerted a profound ideational influence in mid-twentieth century in Brazil, particularly among intellectuals and some bureaucrats working in the governmental agencies in charge of implementing the goals of the administrations of period. One of the main proponents of these new economic notions supporting the goal of fast-paced industrialization was the Brazilian economist Celso Furtado, whose views argued that Latin American economies had traditionally been organized on the basis of a structural co-existence of stagnated productive activities (such as subsistence agriculture) and export-oriented, plantation-based, or mineral extraction, sectors. Based on such a diagnosis, Furtado propounded that effective national development could not occur unless efficient governmental planning in favour a new sort of involvement in the international economy (i.e., ones less dependent on primary-export revenues) would take place.

In Furtado's words,

'[o]ur countries can no longer depend on the exporting of primary products to sustain their economies. The first task that we as nations must undertake is to reorient our investment policies towards the promotion of industrialization so that our commercial balance can be made even. Additionally, given that industrial promotion leads to gains of scale and technological innovation, promoting this goal should benefit our entire economies.'3

${ }^{3}$ Celso Furtado, Manual of Programming and Economic Development Promotion. (Rio de Janeiro: Economic Commission of Latin American, 1956), chapter 1, p. 8, available at Arquivo Roberto Campos: R.C. e bnde 1952.09.29. e/BNDE, available at CPDOC, Getulio Vargas Foundation, in Rio de Janeiro. 
It is clear therefore that since early in the decade and progressively as the 1950s unfolded, ECLA's notions were progressively turning into a common currency among many technocrats and decision-makers in Brazil. How these developmental dynamics were articulated in Brazil in the second half of the decade will occupy us next. This was the period when, under the stewardship of the Kubitschek administration, the country would witness the deepening of the process of industrialization by making available industrialized durable and capital-goods by attracting multinational corporations to set shop in the country.

\section{THE KUBITSCHEK YEARS AND THE DISPUTES AROUND THE CONSOLIDATION OF FAST-PACED INDUSTRIAL PROMOTION}

In October 1955, Juscelino Kubitschek de Oliveira was elected President of Brazil after having run a successful campaign that promised fifty years of economic growth and development in the five years of his presidential term. Indeed, the expression 'Fifty Years in Five' was the catchphrase of the candidate's political platform, and, in general lines, the defining direction of his ensuing administration. During the subsequent five years, Kubitschek, commonly known in Brazil simply as JK, would lead a series of state reforms that, by extending Vargas' policies, aimed at implementing an ambitious plan of economic growth centred on industrial promotion as the basis of an alliance between government and private interests. A clear indication of his developmental agenda, in his first day in office Kubitschek created the Council of Development, an autonomous bureaucratic agency devised to coordinate the implementation of the economic projects of the administration. ${ }^{4}$

The plan would receive the appellation of Targets Plan, given its list of thirty priority targets for the national economy that should receive preferential treatment on the part of the Federal administration. ${ }^{5}$ During the implementation of the Plan (1956-1961), 350 billion cruzeiros were invested in multiple sectors of the economy, which demonstrated the commitment of JK's administration with the goals of national-developmentalism. Insofar as the Plan's impacts in the country's productive structure, during the JK administration important sectors of the Brazilian economy, such as energy production, transportation networks, and the durable goods industry, would all be significantly expanded. To better illustrate this point it is important to state that in 1953 the proportion of traditional consumer goods in the total value of manufacturing output was $58.6 \%$ (with capital goods repre-

\footnotetext{
${ }^{4}$ Presidential Decree, number 38.744, of February 1, 1956, creating the Development Council, in Fundo Conselho do Desenvolvimento. 1Q, SDE, Box 3130. Arquivo Nacional. Rio de Janeiro.

${ }^{5}$ The Plan was divided into five main areas of the national economy which should be favored during the five-year presidential term for receiving priority targeted investments. These included energy supply, transportation networks, basic industries, agricultural production, and technical training and education. For a synthetic list of economic projects or targets contained in the Targets Plan, see Faro and Silva (1991); Lafer (2002); and Lessa (1964).
} 
senting the rate of $5.4 \%$ ), whereas in 1958 this proportion had shrank to $52.6 \%$ (whilst capital goods had increased to $12.3 \%$ ), according to various sources quoted in Tyler (1976). If this new industrial phase partially derived from the larger availability of private international capital, the main reason for the fast-paced industrial growth was the purposeful effort on the part of the Brazilian Federal Government. ${ }^{6}$

Much of these economic achievements depended on the existence of a new conception about development promotion within the Brazilian bureaucracy which benefited from a growing number of centres of excellence in training and research previously established by President Vargas. While Vargas and his economic advisers believed that state-owned companies should be created in order for industrial growth to take place during his second term in office (1951-54), his market-oriented political opponents propounded the need for lower import tariffs on industrialized goods and better conditions for attracting private foreign investors. These different views on what national development should mean fostered a rich ideological debate among socio-political segments in the subsequent administration of Kubitschek (1956-1961) and the President himself would fluctuate between paying lip-service to ECLA's autonomist developmental notions and support a path of economic promotion largely structured on the basis of opening the national economy to foreign multinational interests.

In the first front, Kubitschek even helped disseminate and consolidate some of ECLA's core notions early in his administration. In fact, in his very first Message to the National Congress, in February 1956, for instance, JK expressed his concurrence with the notion of a progressive deterioration in the international terms of trade for primary products (Oliveira, 1956, p. 14). Similarly, during his national campaign, the future president had already stated that:

' $t$ t]he world today is divided between countries that are part of the industrial age and those that continue to be exporters of primary produces and importers industrial goods. (...) Given that the prices of the former are increasingly lower than the prices of the latter, there is a persistent tendency towards unbalanced current accounts that can only be resolved by a steadfastness action on the part of the Federal State in promoting a national project of industrialization'. (Oliveira, 1955, p. 32)

These pronouncement notwithstanding, and even though he was a charismatic politician who believed in the need for fast-paced economic growth for all sectors of society, Kubitschek would constantly rely on more market-oriented technocrats for the execution of his developmental agenda. Namely, and as will detailed

\footnotetext{
${ }^{6}$ Largely due to the economic assistance provided by the United States and the multilateral financial institutions set up after the World War II, Western Europe and Japan were able to restructured their economies within the first 10 years after the conflict, and by the second half of the 1950s were, once again, seeking for investment opportunities in Asia, Europe, and in Latin America.
} 
below, JK's long-time economic adviser Lucas Lopes and the career diplomat Roberto Campos were behind the formulation and execution of the Targets Plan when they headed the two main governmental agencies in charge of the administration's growth promotion goals: The Council of Development and the National Bank of Economic Development. As indicated earlier, while largely inspired on security concerns (i.e., social stability) in tune with Cold War dynamics of the time, Kubitschek's goals nonetheless reverberated well among nationalist intellectuals gathered around the state-funded Higher Institute of Brazilian Studies (ISEB) who argued in favour of a much more ambitious and socially inclusive view of development.

Created in 1955 as an official agency of the Ministry of Education and Culture, the Institute nonetheless was largely autonomous to pursue its own course of intellectual formulations, increasingly more nationalistic and socially oriented as the decade progressed. ISEB members strongly believed that development and nationalism were intrinsically related and, therefore, had to be articulated in tandem should, what they defined as, the 'condition of underdevelopment' the country faced were to be surpassed. Moreover, these intellectuals favoured a much more autonomous and nationalist path of industrialization. Similarly, ISEB ideologues, such as Roland Corbisier, Cândido Mendes de Almeida, Alvaro Vieira Pinto, Guerreiro Ramos, and even the more moderate Hélio Jaguaribe, all consistently argued that the Brazilian government should seek a more independent path of economic insertion in the international economy, if possible by subscribing to the main principles enunciated at the Bandung Conference (e.g., non-intervention, equitable terms of trade, and multilateral support for the process of industrialization), which were all seen as the most efficient way to promote national development in agriculture-based economies (Almeida, 1963; Corbisier, 1959, Jaguaribe, 1953, 1954; Pinto, 1960; and Ramos, 1958).

In direct opposition to the core statist developmental views espoused by most members of ISEB, Kubitschek consistently defended the view that the measure for attesting the existence of national development did not rest only on claims for political autonomy or on demands for social inclusion but rather on the governmental capacity of preventing social disruption caused by poor economic growth. This point is well illustrated in a speech JK pronounced at the Inaugural Lecture for the academic activities of ISEB in 1956, when he declared that:

'[w]e are true nationalists not because we are xenophobic but because we search national solutions for our problems. We welcome and request support to our efforts coming from abroad, such as investment capital, equipments and technical assistance (...) [which] are not the factors that maintain us in our underdeveloped state, which is rather caused precisely by the absence of foreign productive investments' (Oliveira, 1958, p. 48).

Along very similar lines, and clearly exemplifying Kubitschek's complex set of influences, one of the leading figures in the formulation and implementation of the 
Targets Plan, the future Brazilian ambassador to the United States, Roberto Campos - who held leading post at the National Bank of Development and at the Council of Development during JK's mandate - believed that the reasons for the economic underdevelopment of the country rested mainly in the absence of investment capital and the low purchasing power of its population. In his view, what was primarily required for economic development to take place was attracting large sums of foreign investment to selected economic projects (Campos, 1956, p. 232).

Campos also argued against the notion that the Federal government should seek to attend basic social needs of the population by becoming the main promoter of economic development via excessive public expenditures. In his own words, 'the option of development requires above all the acceptance by everyone that fast economic growth, not socially oriented disbursement, is the main task at hand and the only way to reduce social economic inequalities. ${ }^{7}$ Moreover, the market-oriented Campos disagreed with ISEB's standpoints and repeatedly warned that the goal of industrialization should not be promoted at the cost of inflation (i.e., at the expense of public funds). As he put it,

'[n]o one can contest the gains poor countries received from the process of industrialization. This is indeed a vital element of political stability in developing countries. This goal must be promoted even if protectionist measures have to be adopted. However, no one should believe that social upward mobility for all social segments is an immediate outcome of such undertaking nor that inflationary growth can improve the conditions of living in the long run. ${ }^{8}$

Analogous claims were uttered by Lucas Lopes, the main formulator and first coordinator of the implementation of the Targets Plan. In concrete terms, in a speech pronounced at a welcoming reception for the U.S. Secretary of State John Foster Dulles, in 1958, when serving as Minister of the Economy, Lopes declared that Brazil represented the best place for U.S. investments the region. In his view, Brazil could resolve its internal social ills, which represented welcoming grounds for foreign ideologies, only if private sources of capitals were favoured within an attractive framework for foreign investors. ${ }^{9}$ Lopes indeed believed that the main task that the administration should take upon was controlling inflationary spending and targeting public investments exclusively into what was perceived as the main economic bottlenecks or infrastructure hurdles that prevented the achievement of higher eco-

\footnotetext{
${ }^{7}$ Speech Pronounced at ISEB's Inaugural Lecture on December 21 1955, p. 51, in Fundo Roberto Campos: RC.e.bnde.1955.06.30, available at CPDOC, Getúlio Vargas Foundation in Rio de Janeiro.

${ }^{8}$ Campos' Lecture at the University of Arizona in 1960, in Fundo Roberto Campos: RC.e.ag.1955.05.02, available at CPDOC, Getulio Vargas Foundation, in Rio de Janeiro.

${ }^{9}$ Fundo Lucas Lopes: LL pi Lopes, L 1958.08.06, available at CPDOC, Getulio Vargas Foundation, in Rio de Janeiro.
} 
nomic rates of growth. ${ }^{10}$ Later the same year Lopes went to New York University where he lectured on the relations between Brazil and the United States. On that occasion he expressed an optimistic reading of the Brazilian economy and stressed his choice in favour of a market-based path of development for the country. Lopes similarly voiced the position that controlling the rising popular demands (e.g., for salary increases) should be an urgent political task given that these would pressure public expenditures and cause inflation to rise, thus jeopardizing, in this view, the entire developmental initiatives undertaken by the administration. ${ }^{11}$

Taken together these notions illustrate well the commitments of the federal administration in pursuing a market-oriented path of fast economic growth instead of a more inclusive project of national development. It is not surprising therefore that, despite the existence of alternative views on national development, the main political operators in the administration would favour private economic agents and fiscal responsibility instead of job creation and a more autonomous developmental course. In fact, one of the most important achievements of the JK Years - and one praised largely in the literature on the developmental period in Brazil - was that of attracting multinational auto-making corporations to set shop in the country. And while important in deepening the process of industrialization, these companies did not however provide sufficient jobs for the growing masses of migrants moving to the urban centres in the period, nor did they provide, in the long run, manufactured competitive products given their assured market-share (Baer, 1965; Gordon and Grommers, 1960; and Latini, 1984).

\section{WHAT DEVELOPMENT? CLASS STRUCTURE AND THE ROLE OF THE STATE IN DEVELOPMENT PROMOTION}

In a general sense the Brazilian society in the 1950s was still profoundly characterized by the same sociological elements of the long durée that characterized the organization of the country since colonial times, such as the inequalities between city and countryside, the hierarchical and centralized society, and the territorial expansion of the economy continuously engulfing the perceived abundance of natural resources. It was against this background that, because of a favourable national and international conjuncture, the adoption of economic strategies based on the steel industry and urban expansion starting in the 1940s would be made possible.

In concrete terms, the national state through its more qualified agencies played a central role in the comprehensive process of economic transformation the coun-

\footnotetext{
${ }^{10}$ Speech Pronounced at the Annual Meeting of the World Bank in May 1958, in Fundo Lucas Lopes: LL Lopes, L 1958.00.00, available at CPDOC, Getulio Vargas Foundation, in Rio de Janeiro.

${ }^{11}$ Fundo Lucas Lopes: LL pi Lopes, L 1958.12.01, available at CPDOC, Getúlio Vargas Foundation in Rio de Janeiro.
} 
try witnessed in the second half of the $20^{\text {th }}$-century. In fact, resorting to a combination of repression, persuasion, and paternalism, the national state took a significantly political and economic responsibility in the social, material and symbolic modernization of many sectors of the national Brazilian society. Internal disputes within the intellectual and economic elite revealed the politicised nature of state intervention, to the extent that the benefits were highly unevenly distributed across society and geographical locations. Moreover, the controversies and hesitations that characterized the 1950s in Brazil provided invaluable opportunities for the stronger groups of interest to capture the functioning of public agencies according to their particular demands. These intense and highly contradictory dynamics were only momentarily contained by the charismatic influence of two gifted political leaders: Vargas and Kubitschek (Weyland, 1998).

Of special importance, the JK administration in the second half of the decade transcended its immediate historical moment and the material achievements of his term of office. This may help explain the mystique surrounding the so-called 'Kubistchek Years' which still serves as an evocative example of the successful articulation between an appealing personal leader and distinct economic and political achievements. Likewise, if the structure of the state was only partially transformed by this visionary leader, the symbolism of the JK administration certainly represented a phase of intense activity and creative innovation previously unseen in the Brazilian history. ${ }^{12}$

Still, ideological debates regarding the best course of action towards development in the period were clearly demonstrated in the exchanges between organizations such as ECLA and ISEB and the ideas espoused by the Council of Development and the National Bank of Economic Development. Indeed, despite the great influence of liberal technocrats, such as Campos and Lopes, it is important to point out that the JK Years ultimately corresponded to an idiosyncratic, and highly incomplete, Keynesian-reform of the Brazilian state. Notwithstanding the liberal concessions, most strategies and institutional adjustments tried to alleviate uneven geographical development within the national space-economy and promote a stable industrialization (Brenner, 2004, p. 130).

The conditions that emerged in the aftermath of World War II, together with the demands of the geopolitics of the Cold War, paved the road for public policies that more candidly supported import substitution industrialization — already adopted since the end of the nineteenth-century and, more significantly, during the World War I. Similarly, the intense restructuring of state-society relations in the period had also to allow some limited concessions to the working classes, as well as some cohabitation with the demands of rural oligarchy. Moreover, the opportunities created by this peculiar path of development had to be adapted to the unique

\footnotetext{
${ }^{12} \mathrm{Or}$, at least, that was the image that Kubitschek and his supporting group tried to convey with some success, given that all democratically elected presidents in Brazil since the end of the military regime that lasted between 1964 and 1985 have tried to be associated with the image of JK.
} 
circumstances of a country experiencing a fast transition from agrarian to urban society without ever conceding to the more ambitious agenda of social and political reforms.

\section{CONCLUSIONS}

Considering what has been presented it could be stated that, at least in a general sense, the 1950s in Brazil were marked by a search for national development which favoured fast-paced rather than targeted policies aimed at promoting social inclusion and overcoming the poverty that plagued much of the nation. Still, it is interesting to point out that Kubitschek's calls for rapid development and affirmation of national sovereignty capture the public imaginary, even of the lower social strata that benefited less than the middle classes in the period. Indeed, JK's main policies were centred on responding to the crisis of a subordinate industrialization by straightening the internal accumulation of capital and helping the penetration of the national industry by multinational conglomerates, particularly in the automobile sector. The government's position on development promotion was not, however, equally shared by the different groups of the Brazilian society.

In fact, whereas the main agencies in charge of implementing the Targets Plan sought out to implement an ambitious program of economic reforms that deepened the links between domestic production lines and the rapidly expanding international capitalist market; nationalistic intellectuals increasingly argued that promoting national development required decreasing the interconnections between the Brazilian economy and foreign economic interests. Moreover, even if the Kubitschek administration was able to restrain the class conflicts of his time, in the sense that reduced the tension and postponed the looming military coup that would finally take place in 1964, his government was nonetheless affected by its own inconsistencies and the structural contradictions of a dependent capitalist economy.

Perhaps the fate of Brasília epitomizes the shift from an optimistic 1950s to the sombre dictatorial years of the 1960s and 70s. Indeed, the modernist capital designed under the egalitarian inspiration of Lucio Costa and Oscar Niemeyer would subsequently come to represent an authoritarian and inflexible urbanism that proves so alienating to most of its own residents (Williams, 2005). These contradictions continue to haunt Brazilian society and the achievements of national development policies to this day, which only reinforce the relevance of excavating the origin and the legacy of national-developmentalism.

\section{REFERENCES}

ALMEIDA, Cândido Mendes de (1963) Nacionalismo e Desenvolvimento, Rio de Janeiro: Instituto Brasileiro de Estudos Afro-Asiáticos.

BAER, Werner (1965) Industrialization and Economic Development in Brazil, Homewood, Ill.: Irwin. Bandung Conference (1955) Selected Documents of the Bandung Conference. Texts of Selected Speeches 
and Final Communiqué of the Asian-African Conference, Bandung, Indonesia, April 18-24, 1955. Institute of Pacific Relations: New York.

BENEVIDES, Maria Victoria de Mesquita (1976) O Governo Kubitschek: Desenvolvimento Econômico e Establidade Política, 1956-1961, Rio de Janeiro: Paz e Terra.

BRAILLARD, P. and DJALILI, M-R. (1984) The Third World and International Relations, Boulder: Lynne Rienner Publishers.

BRENNER, Neil (2004) New State Spaces: Urban Governance and the Rescaling of Statehood, Oxford: Oxford University Press.

BRESSER-PEREIRA, Luiz Carlos (2006) “De la CEPAL y el ISEB a la Teoría de la Dependencia”, Desarrollo Economico 46 (183): 419-439.

CAMPOS, Roberto (1956) Introdução aos Problemas Brasileiros, Rio de Janeiro: ISEB.

CANAK, William L. (1984) "The peripheral state debate: State capitalist and bureaucratic-authoritarian Regimes in Latin America”, Latin American Research Review 19 (1): 3-36.

CARONE, Edgard (1985) A República Liberal, 1945-1964, São Paulo: DIFEL.

CORBISIER, Roland (1959) Formação e Problema da Cultura Brasileira, Rio de Janeiro: ISEB.

CRAVEY, Altha J. (1998) "Engendering the Latin American state", Progress in Human Geography 22 (4): 523-542.

D’ARAÚJO, Maria Celina Soares (1982) O Segundo Governo Vargas 1951-1954: Democracia, Partidos $e$ Crise Política, Rio de Janeiro: J. Zahar.

DRAIBE, Sônia (1985) Rumos e Metamorfoses: Um Estudo sobre a Constituição do Estado e as Alternativas da Industrialização no Brasil, 1930-1960, Rio de Janeiro: Paz e Terra.

FARO, C. and SILVA, S. (1991) "A década de 50 e o Programa de Metas". In CASTRO GOMES, A., O Brasil de JK. Rio de Janeiro: FGV.

FLEURY, M. T. and FLEURY, A. (2006) "China and Brazil in the Global Economy”, IDS Bulletin 37: 71-79.

Fundação Getúlio Vargas (2001) Dicionário Histórico-Biográfico Brasileiro Pós-30. Coordinated by A. A. Abreu and I. Beloch, Rio de Janeiro: FGV.

FURTADO, Celso (1959) Formação Econômica do Brasil, São Paulo: Fundo de Cultura.

FURTADO, Celso (1961) Desenvolvimento e Subdesenvolvimento, Rio de Janeiro: Fundo de Cultura.

FURTADO, Celso (1985) A Fantasia Organizada, Rio de Janeiro: Paz e Terra.

GEDDES, Barbara (1994) Politician's Dilemma: Building State Capacity in Latin America, Berkley: UC Press.

GLASSMAN, Jim (1999) “State power beyond the 'territorial trap': The internationalization of the state”, Political Geography 18 (6): 669-696.

GORDON, L. and GROMMERS, E. L. (1960) United States Manufacturing Investment in Brazil: The Impact of Brazilian Government Policies, 1946-1960, Cambridge, Mass.: Harvard Graduate School of Business Administration.

GRAMSCI, Antonio (1971) Selections from the Prison Notebooks. Trans./Edit. Q. Hoare and G. N. Smith, London: Lawrence and Wishart.

GUIMARÃES, Alexandre Queiroz (2005) "Historical Institutionalism and Economic Policymaking Determinants of the Pattern of Economic Policy in Brazil, 1930-1960", Bulletin of Latin American Research 24 (4): 527-542.

IANNI, Octávio (1963) Industrialização e Desenvolvimento Social no Brasil, Rio de Janeiro: Civilização Brasileira.

IANNI, Octávio (1986) Estado e Planejamento Econômico no Brasil, Rio de Janeiro: Civilização Brasileira.

JAGUARIBE, Hélio (1953) “A crise brasileira”, Cadernos do Nosso Tempo 1 (1): 121.

JAGUARIBE, Hélio (1954) “Situação política brasileira”, Cadernos do Nosso Tempo 2 (2): 111.

JAGUARIBE, Hélio (1965) “The dynamics of Brazilian nationalism”. In VELIZ, C., Obstacles to Change in Latin America. London: Oxford University Press.

JESSOP, Bob (1990) State Theory, University Park, PA: Pennsylvania State University Press.

JESSOP, Bob (2007) "From micro-powers to governmentality: Foucault's work on statehood, state formation, statecraft and state power", Political Geography 26 (1): 34-40.

JESSOP, Bob (2008) State Power: A Strategic Relational Approach, Cambridge: Polity Press. 
KING, Timothy (1970) Mexico: Industrialization and Trade Policies since 1940, London and New York: Oxford University Press.

LAFER, Celso (2002) JK e o Programa de Metas (1956-1961): Processo de planejamento e sistema politico no Brasil, Rio de Janeiro: FGV.

LATINI, Sydeney A. (1984) Suma Automobilística — volume 1, Rio de Janeiro: Tama.

LEFF, Nathaniel H. (1968) Economic Policy-Making and Development in Brazil, 1957-1960, New York: Wiley.

LESSA, Carlos (1964) "Fifteen years of economic policy in Brazil”, Economic Bulletin for Latin America 9 (2): 153-214.

LOBO, Valéria Marques (2009) "Desmercantilização do trabalho da perspectiva do movimento sindical (Brasil, 1950-2000)”, Dados 52 (1): 85-121.

LOVE, Joseph L. (1980) "Raul Prebisch and the origins of the doctrine of unequal exchange", Latin American Research Review 15 (3): 45-72.

LOVE, Joseph L. (1998) A Construção do Terceiro Mundo: Teorias do Subdesenvolvimento na Romênia e no Brasil, São Paulo: Paz e Terra.

MARTINS, Luciano (1968) Industrialização, Burguesia Nacional e Desenvolvimento, Rio de Janeiro: Saga.

NAPOLEÃO, Aluízio (1988) Juscelino Kubitschek: Audácia, Energia, Confiança, Rio de Janeiro: Bloch.

OFFE, Claus (1996) Modernity and the State: East, West, Cambridge: Polity Press.

OLIVEIRA, José Aparecido de (1991) JK: O Estadista do Desenvolvimento, Brasília: Memorial JK.

OLIVEIRA, Juscelino Kubitschek (1955) Diretrizes Gerais do Plano Nacional de Desenvolvimento, Belo Horizonte: Livraria Oscar Nicolai.

OLIVEIRA, Juscelino Kubitschek (1956) Mensagem ao Congresso Nacional, Rio de Janeiro: Departamento de Imprensa Nacional.

OLIVEIRA, Juscelino Kubitschek (1958) Discursos Proferidos no ISEB no Ano de 1956, Rio de Janeiro: ISEB.

PINTO, Álvaro Vieira (1960) Ideologia e Desenvolvimento Nacional, Rio de Janeiro: ISEB.

RAMOS, Alberto Guerreiro (1958) A Redução Sociológica, Rio de Janeiro: ISEB.

RODRIGUES, Marly (1994) A Década de 50: Populismo e Metas Desenvolvimentistas no Brasil, São Paulo: Atica.

RODRIGUES, Octavio (1981) Teoria do Subdesenvolvimento da Cepal, Rio de Janeiro: Forense Universitária.

SAAD-FILHO, A. and JOHNSON, D. (2005) Neoliberalism: A Critical Reader, London: Pluto Press.

SILVA, H. and CARNEIRO, M. (1983) Juscelino, o Desenvolvimento, 1956-61, São Paulo: Editora Três.

SKIDMORE, Thomas E. (1967) Politics in Brazil, 1930-1964: An Experiment in Democracy, Oxford: Oxford University Press.

STALLINGS, Barbara B. (1978) Class Conflict and Economic Development in Chile, 1958-1973, Stanford: Stanford University Press.

TYLER, William (1976) "Brazilian industrialization and industrial policies: A survey", World Development 4 (10-11): 863-882.

VEGANZONES, Marie-Ange, with Winograd, C. (1997) Argentina in the 20th century: An Account of Long-awaited Growth, Paris: OECD.

WEFFORT, Francisco Correa (1978) O Populismo na Política Brasileira, Rio de Janeiro: Paz e Terra.

WELCH, Cliff (2006) "Keeping communism down on the farm: The Brazilian rural labor movement during the Cold War", Latin American Perspectives 33 (3): 28-50.

WEYLAND, Kurt (1998) "From Leviathan to Gulliver? The decline of the developmental state in Brazil", Governance 11 (1): 51-75.

WILLIAMS, Richard J. (2005) “Modernist civic space and the case of Brasília”, Journal of Urban History 32 (1): 120-137.

WILLIS, Eliza J. (1995) "Explaining bureaucratic independence in Brazil: The experience of the National Economic Development Bank", Journal of Latin American Studies 27 (3): 625-661.

WISE, Carol (2003) Reinventing the State: Economic Strategy and Institutional Change in Peru, Ann Arbor: University of Michigan Press. 